\title{
DISCRIMINATION OF EUTERPE OLERACEA MART. (AÇAÍ) AND EUTERPE EDULIS MART. (JUÇARA) INTACT FRUIT USING NEAR-INFRARED (NIR) SPECTROSCOPY AND LINEAR DISCRIMINANT ANALYSIS
}

\author{
YARA GURGEL DALL' ACQUA ${ }^{1 *}$, LUIS CARLOS CUNHA JÚNIOR ${ }^{1 *}$, VIVIANI NARDINI ${ }^{1}$, \\ VALQUIRA GARCIA LOPES ${ }^{2}$, JOSÉ DALTON DA CRUZ PESSOA ${ }^{2}$ and \\ GUSTAVO HENRIQUE DE ALMEIDA TEIXEIRA ${ }^{3,4 *}$
}

\begin{abstract}
'Departamento de Análises Clínicas, Toxicológicas e Bromatológicas, Faculdade de Ciências Farmacêuticas de Ribeirão Preto (FCFRP), Universidade de São Paulo (USP), Ribeirão Preto, SP, Brazil

2Instrumentação Agropecuária, Empresa Brasileira de Pesquisa Agropecuária (EMBRAPA), São Carlos, SP, Brazil

${ }^{3}$ Departamento de Produção Vegetal, Faculdade de Ciências Agrárias e Veterinárias, Universidade Estadual Paulista (UNESP), Via de Acesso Prof. Paulo Donato Castellane s/n, CEP 14884-900, Jaboticabal, SP, Brazil
\end{abstract}

\author{
${ }^{4}$ Corresponding author. \\ TEL: +55-16-32097532; \\ FAX: +55-16-3209-2668; \\ EMAIL: gustavo@fcav.unesp.br \\ Received for Publication December 3, 2014 \\ Accepted for Publication June 4, 2015 \\ doi:10.1111/jfpp.12536 \\ *These authors contributed equally to this \\ study.
}

\begin{abstract}
As the verification of authenticity of agricultural foods has become a potential application of spectroscopic methods, this study aimed to use near-infrared (NIR) spectroscopy associated with linear discriminant analysis (LDA) to discriminate intact fruit of the species Euterpe oleracea Mart. (açaí) and Euterpe edulis Mart. (juçara). One hundred sixty-eight açaí fruits from 17 genotypes and 200 fruits from 20 juçara genotypes were investigated and two groups were used for discriminating the species: calibration (294 fruits) and prediction (74 fruits). $L^{\star}, a^{*}$, $b^{*}$-PCA, and NIR-PCA of spectra pretreated with multiplicative scatter correction (MSC) showed the best results. The $L^{*}, a^{*}, b^{*}$-LDA model resulted in $96.3 \%$ correct classification and $93.2 \%$ prediction accuracy of the external validation group. NIR spectra pretreated with MSC had $98 \%$ correct classification and $97.3 \%$ prediction accuracy. NIR spectroscopy associated with LDA is a reliable method for the discrimination of intact açaí and juçara fruit.
\end{abstract}

\section{PRACTICAL APPLICATIONS}

Recently, there has been an increasing interest by food industry and producers to assure consumers the authenticity of their products. Many food properties are related to individual compounds and their active chemical ingredients, such as essential oils, terpenoids, flavonoids, phenolic compounds, amino acids and organic acids. The Euterpe genus has many species of economic interest and E. oleracea (açaí or assai), E. edulis (juçara) and E. precatoria are among the most important species in the agribusiness sector. As the fruit of these species are morphologically similar, it is important to develop instrumental methods to sort these fruit at the convey belt in order to ensure authenticity and near-infrared (NIR) spectroscopy can be used for that. Based on our results, the NIR spectroscopy and chemometrics provide a useful approach for authenticating fruit from Euterpe genus and can be used by the food industry to identify adulteration.

\section{INTRODUCTION}

Tropical biomes in Brazil are rich in plant species of economic interest such as the palms in the genus Euterpe
(Arecaceae). Henderson et al. (1995) reported that the species of this genus found in the Brazilian Amazon are E. oleracea, E. precatoria var. precatoria, E. precatoria var. longevaginata, E. catinga var. catinga, E. catinga var. 
roraimae and E. longibracteata. Moreover, E. oleracea (açaí palm or açaí), E. edulis (juçara palm) and E. precatoria are among the most important species in the agribusiness sector (Oliveira et al. 2000).

The açaí palm, which is native to the Brazilian Amazon (Conforto and Contin 2009), is an allogamous, perennial palm propagated almost exclusively by seed (Neto and Oliveira 2005), resulting in high genetic variability (Neto et al. 2003). The açaí fruit is a globose drupe $1-2 \mathrm{~cm}$ in diameter. The epicarp can be green or purple. The mesocarp is pulpy and thin, about $1 \mathrm{~mm}$ thick, and surrounds the voluminous and hard endocarp, which contains a single yellowish-brown seed (Nascimento 2008). Juçara palm can be found from southern Bahia state $\left(15^{\circ} \mathrm{S}\right)$ to northern Rio Grande do Sul state $\left(30^{\circ} \mathrm{S}\right)$ in the Atlantic Forest domain (Marcos and Matos 2003). The species is monoecious and preferentially allogamous (Marto 2007). According to Queiroz (2000), juçara fruit are drupaceous, fleshy-fibrous, spherical, nearly black or black-vinous, bright when mature, and animal dispersed. The seeds are $1 \mathrm{~cm}$ in diameter and have high energy reserves of carbohydrates $(88 \%)$, proteins $(10 \%)$ and lipids (2\%) (Marto 2007).

These palm species are highly appreciated worldwide and have multiple uses, leading to increased demand in national and international markets. In southern and southeastern Brazil, the fruit are highly appreciated as frozen pulp ready for consumption due to their nutritional energy value and functional properties, including antioxidant capacity (Faria et al. 2012). In addition, due to their high anthocyanin content, the fruit can also be used for animal feed production and human consumption as pulp, often as an açaí and juçara mix (Marto 2007). According to Oliveira and Neto (2005), trade in açaí pulp has been growing considerably in the recent years, both in Brazilian states (Southeast, Northeast and Midwestern regions), with a demand of approximately 850 tons/month, and to other countries, exceeding 120 tons/year. As the palm fruit from Euterpe genus are morphologically similar, to supply this growing pulp demand, other species rather than E. oleracea Mart. (açaí) have been used and labeled as açaí. False use of food indications by unauthorized parties is detrimental to consumers and legitimate producers (Cozzolino 2012).

Anthocyanins, the main attractive compounds in the pulp of these fruit, are phenolic flavonoids that act as colorants (Lopes et al. 2007) and natural antioxidants, and which can react with free radicals in the body (Cohen et al. 2006). Additionally, they have protective effects against cardiovascular diseases and cancer (Silva and Lopes 2006). According to Iaderoza et al. (1992), anthocyanin contents in juçara and açaí fruit are 1,374 mg/100 g and $336 \mathrm{mg} / 100 \mathrm{~g}$, respectively. The fruit also differ in calorie content: juçara pulp has a higher average amount of total sugars and lipids than açaí (Silva et al. 2004), whereas the soluble solid content of juçara pulp is $3.03{ }^{\circ}$ Brix (Ribeiro et al. 2011) and of açaí pulp is $2.7^{\circ} \mathrm{Brix}$ (Nascimento 2008). In addition, the levels of phosphorous and copper are higher in açaí than in juçara pulp.

The differentiation of the species can be achieved through the analysis of morphological aspects (Lorenzi 1992) and/or the chemical composition of their fruit (Iaderoza et al. 1992; Silva et al. 2004; Ribeiro et al. 2011). However, most differentiation methodologies used are destructive, expensive, time-consuming, and demand trained personnel and chemical reagents. Thus, a rapid, nondestructive, residue-free, low-cost technique such as near-infrared (NIR) spectroscopy or evaluation of epidermal color can be used in these cases. NIR spectroscopy exploits the variety of physicochemical information provided by the product spectra, using chemometric techniques to extract relevant information from samples (Pasquini 2003).

Satisfactory results were achieved in the association between medium infrared spectra and linear discriminant analysis (LDA) technique for the separation of coffee species Coffea arabica and Coffea canephora var. robusta (Kemsley et al. 1995). Chen et al. (2008) used NIR spectroscopy combined with chemometric analyses for the separation of Ganoderma lucidum varieties from six geographic origins and achieved satisfactory classification results. He et al. (2006) performed quantitative analyses in samples from eight tea varieties using NIR spectroscopy in association with principal component analysis (PCA) and Wavelet transforms (WT). Ruoff et al. (2006) used NIR spectroscopy associated with PCA and LDA for the authentication of the botanical origin of honey and showed the applicability of this technique in standard discrimination. Ferrer et al. (2011) developed accurate models using NIR technology associated with chemometric tools to determine the concentration of total polyphenols in intact grapes. Moreover, a recent study demonstrated the feasibility of using NIR spectroscopy to predict anthocyanin content in açaí and juçara fruit (Inácio et al. 2013).

The use of Commission Internationale de L'Eclaraige (CIE) color parameters $L^{\star}$ (lightness), $a^{\star}$ (red, greenness) and $b^{\star}$ (yellow, blueness) has been little explored for plant classification. Salces et al. (2005), using the CIE system, achieved $90 \%$ accuracy in the classification of ciders from different regions.

As the verification of the authenticity of natural and agricultural foods has become a potential application of spectroscopic methods, this study aimed to classify intact fruit from the species E. oleracea Mart. (açaí) and E. edulis Mart. juçara using NIR spectroscopy and the CIE color system associated with PCA and LDA. 


\section{MATERIALS AND METHODS}

\section{Plant Material}

In order to introduce a broad range of environmental aspects into the dataset, the fruit of açaí and juçara were harvested from different genotypes; as these palm species are considered wild, the genotypes have large genetic variability. The fruit were also obtained in two different harvest seasons (2010 and 2011) and from different growing regions with different soil types.

Fruit from seven açaí and juçara genotypes were collected in 2010 and from 13 juçara genotypes and 10 açaí genotypes in 2011. The genotypes were grown in different localities (four cities in the state of São Paulo, Brazil: Jaboticabal $21^{\circ} 15^{\prime} \mathrm{S}, 48^{\circ} 15^{\prime} \mathrm{W}$ and $560 \mathrm{~m}$ a.s.l.; Ubatuba - $23^{\circ} 27^{\prime} \mathrm{S}$, $45^{\circ} 04^{\prime} \mathrm{W}$ and $8 \mathrm{~m}$ a.s.l.; Araraquara - $21^{\circ} 47^{\prime} 37^{\prime \prime} \mathrm{S}$, $48^{\circ} 10^{\prime} 52^{\prime \prime} \mathrm{W}$ and $646 \mathrm{~m}$ a.s.l.; and Ribeirão Preto $21^{\circ} 12^{\prime} 42^{\prime \prime} \mathrm{S}, 47^{\circ} 48^{\prime} 24^{\prime \prime} \mathrm{W}$ and $546 \mathrm{~m}$ a.s.l.).

From each genotype, one panicle was collected at the stage of commercial maturity (completely purple fruit), totaling 37 panicles. Panicles were threshed manually and damaged fruit, those with mechanical injuries and/or injuries caused by insects, and out-of-standard (green) fruit were removed.

The intact fresh fruit were placed into plastic bags, identified and taken to the laboratory. In the laboratory, the fruit were kept at room temperature $(25 \mathrm{C})$ for $1 \mathrm{~h}$ until uniform temperature was achieved. Ten to nine fruits were randomly sampled from each genotype, totaling 368 fruits (200 juçara and 168 açaí), and individually analyzed for color (CIE) and NIR diffuse reflectance.

\section{Fruit Color}

Color measurement was performed individually at three sites on the equatorial line of each intact fresh fruit (whole) using a Minolta CR-400 colorimeter (Minolta Corp., Tokyo, Japan), which measures color according to the CIE system $\left(L^{\star}, a^{\star}, b^{\star}\right)$. In addition, derived parameters such as hue angle $\left({ }^{\circ} h\right), \arctan \left(b^{\star} / a^{*}\right)$ and chromaticity $\left(C^{\star}\right)$ $\left(\left[\left(a^{\star}\right) \times 2+\left(b^{\star}\right) \times 2\right] \times 0.5\right)$ were calculated according to the method described by McGuire (1992).

\section{NIR Spectra}

On the same sites where color was determined of each intact fresh fruit (whole), the NIR spectra were collected using a Spectrum 100N FT-NIR spectrometer (PerkinElmer, Shelton, CT) coupled to a diffuse reflectance cell. Fruit were set on a polytetrafluoroethylene support with an aperture of $0.5-\mathrm{cm}$ diameter placed onto a Near Infrared Reflectance
Accessories (NIRA) (PerkinElmer, PN L125403L). Sixtyfour scans were performed in the spectral range from 4,000 to $10,000 \mathrm{~cm}^{-1}$ at a spectral resolution of $2 \mathrm{~cm}^{-1}$ (Fig. 1). The spectra were acquired using the Spectrum software version 10.03.02 (PerkinElmer).

\section{Pretreatment of Spectra}

As it was collected three spectra per fruit, the mean spectrum was calculated using the Unscrambler $\mathrm{X}$ version 10.1 software (CAMO, Oslo, Norway).

Relevant information from the NIR spectra cannot always be extracted directly from the raw data because the data may not have an appropriate distribution. In this case, pretreatment of spectra is required to adjust the magnitude of spectra to similar values (Johnson and Wichem 1998). Ten pre-processing methods were used comparatively in the NIR spectra. Four isolated pre-processing methods were used, with the standard normal variate (SNV) (Barnes et al. 1993) and multiplicative scatter correction (MSC) (Sabin et al. 2004) methods used to minimize the effect of light scattering caused mainly by the lack of homogeneity of the samples (Naes et al. 2002). Spectra baseline correction was performed using the first and second Savitzky-Golay derivatives (Savitsky and Golay 1964).

Because the association of pre-processing techniques can combine the benefits of the methods (Naes et al. 2002), six pretreatment of spectra combinations were tested. SNV and MSC treatments were associated with the De-trend transformation (Barnes et al. 1993). The association of SNV and MSC with the first and second Savitzky-Golay derivatives was also used (Savitsky and Golay 1964). Pre-processing of spectra was performed using the Unscrambler $\mathrm{X}$ version 10.1 software (CAMO).

\section{Chemometric Methods}

PCA. The association of chemometric methods with NIR spectroscopy for quantitative (Inácio et al. 2013) and qualitative (Chen et al. 2008) analyses of fruit has shown promising results. In this study, PCA was used to determine whether there was group formation between açaí and juçara fruit (Andre 2003) for the separation of species. For color determination, PCAs (Color-PCA) were constructed for all parameter combinations with the $L^{*}$ variable, totaling 15 combinations $\quad\left(L^{*}+a^{*}+b^{*}+C^{*}+{ }^{\circ} h ; \quad L^{*}+a^{*}+b^{*}+C^{*}\right.$; $L^{*}+a^{*}+b^{*}+{ }^{\circ} h ; \quad L^{*}+b^{*}+C^{*}+{ }^{\circ} h ; \quad L^{*}+a^{*}+C^{*}+{ }^{\circ} h ;$ $L^{*}+a^{*}+b^{*} ; \quad L^{*}+C^{*}+{ }^{\circ} h ; \quad L^{*}+a^{*}+C^{*} ; \quad L^{*}+a^{*}+$ ${ }^{\circ} h ; L^{\star}+b^{\star}+{ }^{\circ} h ; L^{*}+b^{*}+C^{\star} ; L^{\star}+b^{*} ; L^{*}+a^{*} ; L^{*}+C^{*}$; and $L^{*}+{ }^{\circ} h$ ) for the separation of açaí and juçara fruit.

NIR spectra PCAs (NIR-PCA) were constructed for spectra with and without pre-processing (totaling 11 


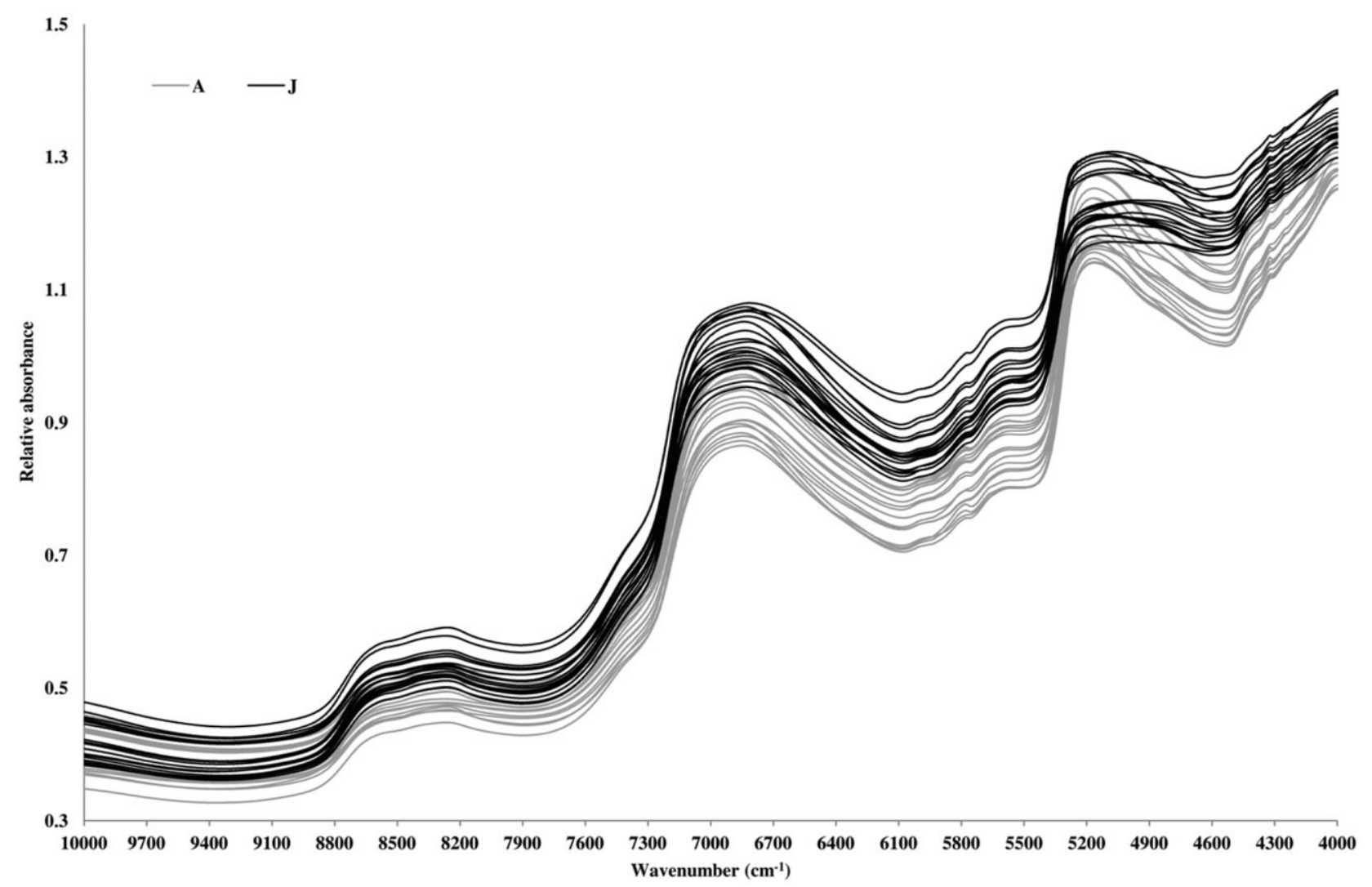

FIG. 1. COMPARISON OF MEAN NEAR-INFRARED SPECTRA FROM DIFFERENT FRUITS OF EUTERPE OLERACEA MART. (AÇAÍ, N=17) AND EUTERPE EDULIS MART (JUÇARA, $N=20$ )

Black lines, juçara; gray lines, açaí.

PCAs) for the separation of species (açaí and juçara).

PCAs were constructed using NIPALS algorithm and random cross-validation with 20 segments for the separation of species, whereas for the separation of species, 20 segments were used for juçara and 13 for açaí. The number of principal components (PCs) was the maximum possible for Color-PCAs (PCs 2-5) and was fixed at 10 PCs for NIRPCAs. All PCAs were constructed using Unscrambler X version 10.1 software (CAMO).

LDA. LDA, a supervised pattern recognition technique (Naes et al. 2002), was used to classify the different açaí and juçara species. LDA models for the separation of species were constructed using the same 15 color parameter combinations and pre-processing of the NIR spectra. The Mahalanobis distance measure was used in LDA models, and the greater the Mahalanobis distance between two samples, the greater their spectral or colorimetric differences (Miralbés 2008). The color LDAs were constructed as proposed by Fisher (1936). However, NIR LDAs were constructed using the first 10 PCs from PCA for the separation of species which were the PCs that accounted for more than $95 \%$ of the total variance of the models. All LDAs were constructed using Unscrambler $\mathrm{X}$ version 10.1 software (CAMO).

\section{RESULTS}

\section{Discrimination of E. oleracea Mart. (Açaí) and E. edulis Mart. (Juçara)}

PCA. The NIR spectra of juçara fruit showed higher relative absorbance values than the spectra of açaí fruit. Comparing some NIR spectra obtained from both species, it is possible to see that the spectra overlap and there is not clear segregation among them (Fig. 1). Given the observed overlap among spectra, the PCA models were trialed to separate the species. The PCA results from color (Color-PCA) and NIR spectra (NIR-PCA) data for the discrimination of açaí and juçara fruit are shown in Fig. 2.

The association between $L^{\star}+a^{\star}+b^{\star}$ produced the best clustering results between the species from the 15 color 
A

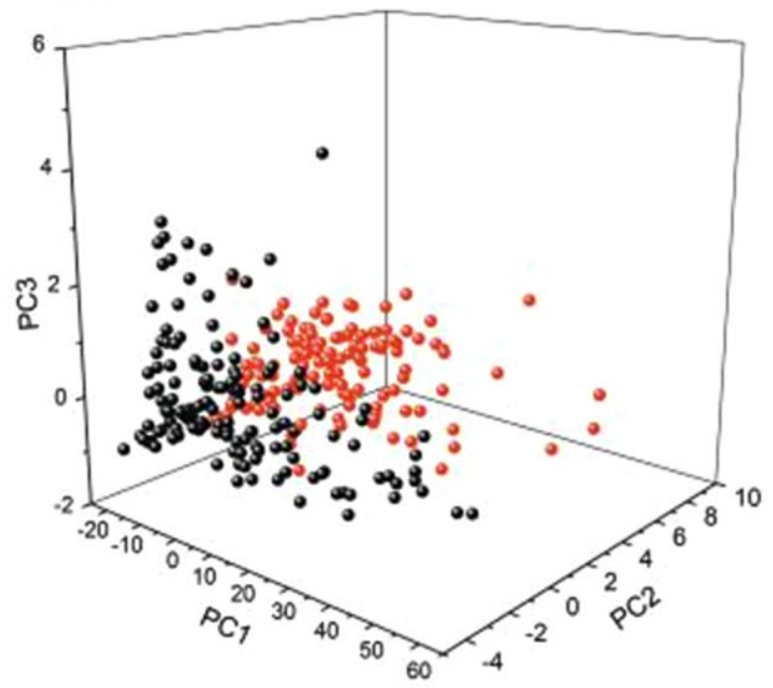

B

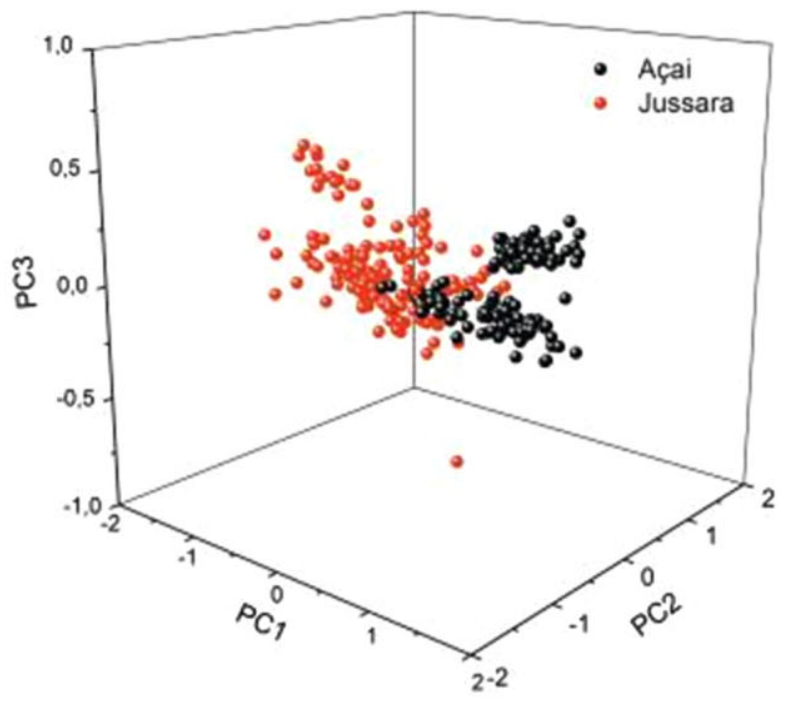

FIG. 2. THREE-DIMENSIONAL PLOT OF THE SCORES FOR THE FIRST THREE PRINCIPAL COMPONENTS (PC1, PC2 AND PC3) AND RESPECTIVE PERCENTAGE VARIATION FOR THE SEPARATION OF EUTERPE OLERACEA MART. (AÇAÍ) AND EUTERPE EDULIS MART (JUÇARA)

(A) $L^{*}, a^{*}, b^{*}$-PCA score plot. (B) NIR MSC-PCA score plot.

parameter combinations (Fig. 2A). PC1 explained 97\% of the variance of the data in the $L^{*}, a^{*}, b^{\star}$-PCA, and açaí fruit tended to cluster on the positive side of PC2, whereas juçara fruit were on the opposite side (Fig. 2A). The PCA loading plot can be seen in Fig. 3a. The PC1 was strongly influenced by the $b^{*}$ color parameters and the PC2 by the $L^{*}$ value with only $2 \%$ of the variance (Fig. $3 \mathrm{~A}$ ).

The best species discrimination was achieved using the MSC from all tested pre-processing methods of NIR spectra, with açaí fruit grouped on the positive side of PC1 and juçara fruit on the opposite side (Fig. 2B). In addition, the PC1 explained $80 \%$ of the variance and the highest loading was around $5,186 \mathrm{~cm}^{-1}$ (Fig. 3B). The PC2 explained $12 \%$ of the variance and the loading plot showed a positive correlation with the region around 6,800$7,100 \mathrm{~cm}^{-1}$ (Fig. 3B). The PC3 showed similar results of PC1 (Fig. 3B).

LDA. The results of LDA models constructed with the 15 color parameter combinations and the prediction with external groups of intact açaí and juçara fruit are shown in Table 1.

The LDA model that showed the best result for the classification and prediction of açaí and juçara fruit was the one constructed with $L^{*}, a^{*}$ and $b^{*}$ parameters, with $96.3 \%$ accuracy for classification and $93.2 \%$ prediction accuracy of the external validation group. The LDA models that showed the worst results were those constructed with $L^{\star}, b^{\star}$,
$C^{\star}$ and ${ }^{\circ} h$, and $L^{\star}, b^{\star}$ and $C^{\star}$ parameters (Table 1).

The results of LDA models constructed with NIR spectra with and without pre-processing of spectra are shown in Table 2.

The LDA models constructed after MSC and SNV + Detrend pretreatments of spectra showed the best results, both with $98 \%$ accuracy on the classification of intact açaí and juçara fruit, and $97.3 \%$ accuracy in predicting the external validation group (Table 2). The models constructed using spectra treated with the second derivative or its combinations (MSC + second derivative and SNV + second derivative) had an inferior performance than the LDA with untreated spectra.

The LDA model of the first derivative showed the worst accuracy $(89.2 \%)$ in the prediction of the external group (Table 2). The models LDA-SNV + De-trend and LDA-MSC had similar results and because LDA-MSC used only one pre-processing method it was considered the best result.

\section{DISCUSSION}

\section{Discrimination of E. oleracea Mart. (Açaí) and E. edulis Mart. (Juçara)}

PCA enabled us to identify the $L^{\star}, a^{*}, b^{\star}$ combination (Fig. 2A) and MSC pre-processing of the NIR spectra 

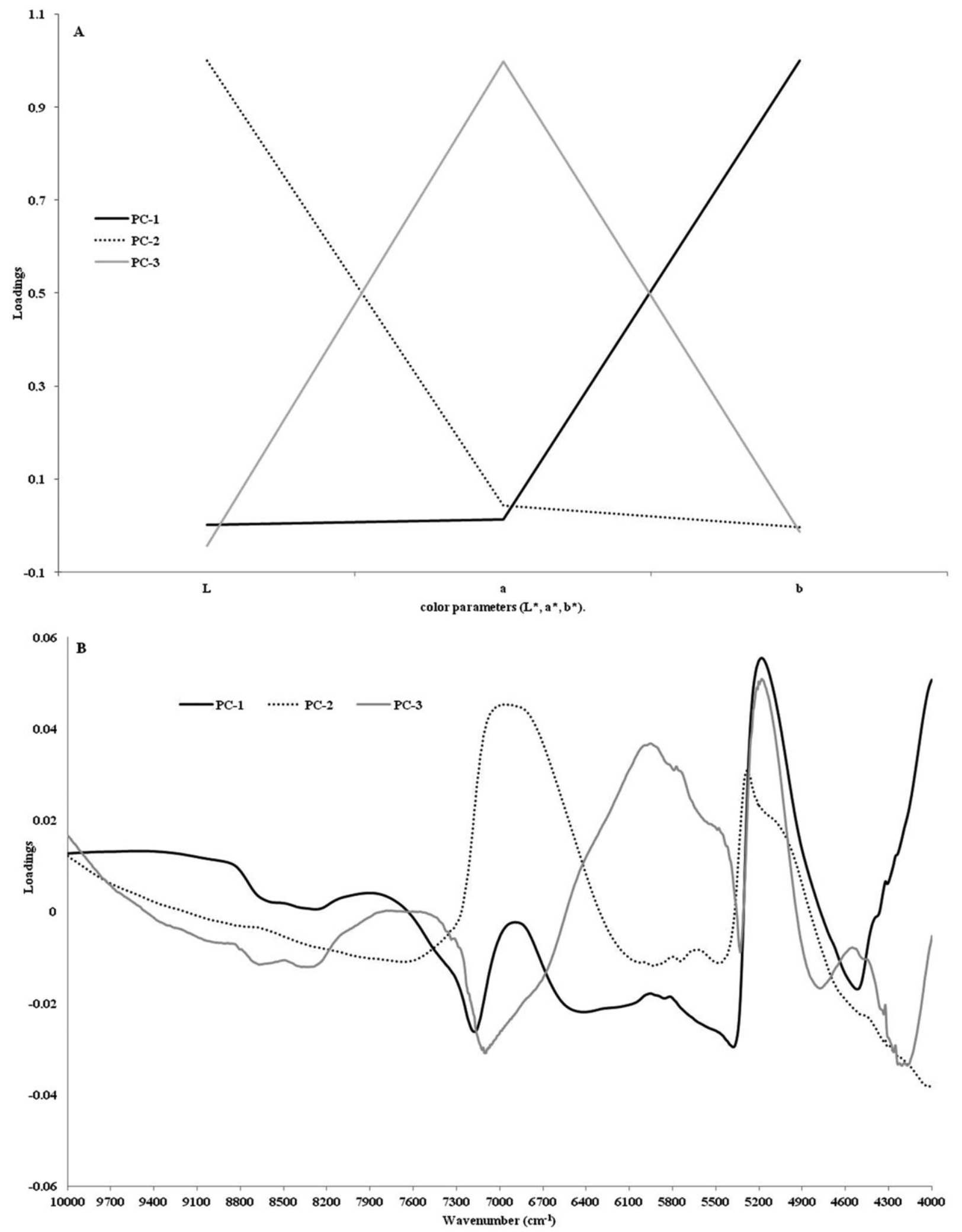

FIG. 3. LOADING PLOTS FOR THE PRINCIPAL COMPONENTS OF (A) $L^{*}, A^{*}, B^{*} C O L O R$ PARAMETERS AND (B) SPECTRA NEAR-INFRARED AFTER MULTIPLICATIVE SCATTER CORRECTION OF EUTERPE OLERACEA MART. (AÇAí) AND EUTERPE EDULIS MART (JUÇARA) 
TABLE 1. CLASSIFICATION AND PREDICTION OF EUTERPE OLERACEA MART. (AÇAÍ) AND EUTERPE EDULIS MART (JUÇARA) USING EPIDERMAL COLOR PARAMETERS $\left(L^{*}, A^{*}, B^{*}\right.$, HUE AND CHROMA) ASSOCIATED WITH LINEAR DISCRIMINANT ANALYSIS

\begin{tabular}{|c|c|c|c|c|c|c|}
\hline \multirow[b]{3}{*}{ Parameters } & \multicolumn{3}{|c|}{ Classification $(n=294)$} & \multicolumn{3}{|c|}{ Prediction $(n=74)$} \\
\hline & \multicolumn{2}{|c|}{ Incorrectly classified samples } & \multirow{2}{*}{$\begin{array}{l}\text { Correct } \\
\text { percent }(\%)\end{array}$} & \multicolumn{2}{|c|}{ Incorrectly classified samples } & \multirow{2}{*}{$\begin{array}{l}\text { Accuracy } \\
\text { rate (\%) }\end{array}$} \\
\hline & Açaí $(n=134)$ & Juçara $(n=160)$ & & Açaí $(n=34)$ & Juçara $(n=40)$ & \\
\hline$L^{*}, a^{*}, b^{*}, C^{*}$ and ${ }^{\circ} h$ & 7 & 7 & 95.2 & 3 & 2 & 93.2 \\
\hline$L^{*}, a^{*}, b^{*}, C^{*}$ & 6 & 6 & 95.9 & 2 & 4 & 91.9 \\
\hline$L^{*}, a^{*}, b^{*}, \circ h$ & 5 & 6 & 96.3 & 1 & 5 & 91.9 \\
\hline$L^{*}, b^{*}, C^{*}$ and ${ }^{\circ} h$ & 7 & 11 & 93.9 & 2 & 4 & 91.9 \\
\hline$L^{*}, a^{*}, C^{*}$ and ${ }^{\circ} h$ & 5 & 6 & 96.3 & 1 & 4 & 93.2 \\
\hline$L^{*}, a^{*}, b^{*}$ & 3 & 8 & 96.3 & 1 & 4 & 93.2 \\
\hline$L^{*}, C^{*}$ and ${ }^{\circ} h$ & 5 & 11 & 94.6 & 1 & 5 & 91.9 \\
\hline$L^{*}, a^{*}, C^{*}$ & 3 & 8 & 96.3 & 1 & 3 & 94.6 \\
\hline$L^{*}, a^{*},{ }^{\circ} h$ & 5 & 8 & 95.6 & 1 & 5 & 91.9 \\
\hline$L^{*}, b^{*}, C^{*}$ & 7 & 10 & 94.2 & 2 & 5 & 90.5 \\
\hline$L^{*}, b^{*},{ }^{\circ} h$ & 5 & 12 & 94.2 & 1 & 5 & 91.9 \\
\hline$L^{*}, b^{*}$ & 2 & 12 & 95.2 & 1 & 5 & 91.9 \\
\hline$L^{*}, a^{*}$ & 3 & 10 & 95.6 & 1 & 4 & 93.2 \\
\hline$L^{*}, C^{*}$ & 2 & 13 & 94.9 & 1 & 5 & 91.9 \\
\hline$L^{*}, \circ$ & 4 & 11 & 94.9 & 1 & 5 & 91.9 \\
\hline
\end{tabular}

(Fig. 2B) as the best treatments for the discrimination of E. oleracea and E. edulis fruit. According to Correia and Ferreira (2007), PCs are arranged in descending order of importance and the greater the variance explained by the first PC, the simpler is the generated model. In fact, the variance explained by $\mathrm{PC} 1$ was $97 \%$ in the $L^{\star}, a^{*}, b^{*}$ combination (Fig. 2A) and $80 \%$ in MSC-PCA (Fig. 2B), which justifies their choice.

Analyzing the PCA loading plot, the PC1 was strongly influenced by $b^{*}$ color parameters and PC2 by the $L^{\star}$ value (Fig. 3A). The $b^{*}$ scale represents the variation in color from yellow to blue where a positive value indicates yellow and a negative value indicates blue (McGuire 1992). As all fruit were harvested in a commercial maturity stage with fruit completely purple, the difference in $b^{*}$ might be related to the anthocyanin, which is a purple pigment. Inácio et al. (2013) have already mentioned that juçara is richer in anthocyanin than açaí fruit and that might have affected the $b^{*}$ color parameter, which leads to a cluster formation. Regarding the $L^{*}$ value, açaí fruit has more wax deposits $(p<0.05)$ on the epidermis, which leads the fruit to present higher $L^{*}$ values $(30.35-31.90)$ in relation to juçara fruit (26.39-26.48). As PC2 was influenced by $L^{\star}$ value and this color parameter was different between these two species, it also might have contributed to group the fruit of both species.

TABLE 2. CLASSIFICATION AND PREDICTION OF EUTERPE OLERACEA MART. (AÇAÍ) AND EUTERPE EDULIS MART (JUÇARA) USING NEAR-INFRARED (NIR) SPECTRA ASSOCIATED WITH LINEAR DISCRIMINANT ANALYSIS

\begin{tabular}{|c|c|c|c|c|c|c|}
\hline \multirow[b]{3}{*}{ Pretreatment of data } & \multicolumn{3}{|c|}{ Classification $(n=294)$} & \multicolumn{3}{|c|}{ Prediction $(n=74)$} \\
\hline & \multicolumn{2}{|c|}{ Incorrectly classified samples } & \multirow{2}{*}{$\begin{array}{l}\text { Correct } \\
\text { percent (\%) }\end{array}$} & \multicolumn{2}{|c|}{ Incorrectly classified samples } & \multirow{2}{*}{$\begin{array}{l}\text { Accuracy } \\
\text { rate (\%) }\end{array}$} \\
\hline & Açaí $(n=134)$ & Juçara $(n=160)$ & & Açaí $(n=34)$ & Juçara $(n=40)$ & \\
\hline No treatment & 7 & 0 & 97.6 & 2 & 0 & 97.3 \\
\hline SNV & 7 & 1 & 97.3 & 2 & 0 & 97.3 \\
\hline MSC & 5 & 1 & 98.0 & 2 & 0 & 97.3 \\
\hline 1st derivative & 7 & 1 & 97.3 & 8 & 0 & 89.2 \\
\hline 2nd derivative & 11 & 5 & 94.6 & 2 & 0 & 97.3 \\
\hline SNV + De-trend & 5 & 1 & 98.0 & 2 & 0 & 97.3 \\
\hline MSC + De-trend & 6 & 1 & 97.6 & 2 & 0 & 97.3 \\
\hline SNV + 1st derivative & 6 & 1 & 97.6 & 2 & 0 & 97.3 \\
\hline SNV + 2nd derivative & 11 & 5 & 94.6 & 2 & 0 & 97.3 \\
\hline MSC + 1st derivative & 6 & 1 & 97.6 & 2 & 0 & 97.3 \\
\hline MSC +2 nd derivative & 11 & 5 & 94.6 & 2 & 0 & 97.3 \\
\hline
\end{tabular}

MSC, multiplicative scatter correction; SNV, standard normal variate. 
The NIR spectra obtained for each species can be called a fingerprint of açaí and juçara, with specific characteristics for each species. In addition, the wavelengths with the highest loading for PC1 and PC2 after MSC pre-processing (Fig. 3B) are correlated with the first overtone of the $\mathrm{OH}$ bonds at $6,952 \mathrm{~cm}^{-1}$ and combination bonds of the asymmetric and scissor stretch $\mathrm{O}-\mathrm{H}$ vibrations at $5,186 \mathrm{~cm}^{-1}$ (Nicolaï et al. 2007). PC3 explained 4\% of the variation and the highest point of loading was around $6,000 \mathrm{~cm}^{-1}$, this spectral region is indicated by first overtone of $\mathrm{CH}$ (Inácio et al. 2013). Those important spectral characteristics were also reported by Inácio et al. (2013) when studying the anthocyanin contents in these species.

Regarding NIR spectroscopy, juçara fruit was richer in total anthocyanin content (2.56-3.94\%) than açaí (1.05$1.22 \%)$, which leads the fruit to have different chemical compositions. Therefore, as already stated for the $b^{\star}$ color parameter, the differences in color can be associated to total anthocyanin content in the epidermis of the fruit, and the NIR spectra were affected to a point that the PCA carried out using the NIR spectra better group the fruit of each species.

Even though PCA could not accurately separate açaí and juçara fruit (Fig. 2), it was the first step toward the detection of patterns for species discrimination. Exploring data with PCA enables the evaluation of similarities between species and the importance of the relationship of the response variables examined (Souza and Poppi 2012).

Plotting principal components (PCs) showed interrelationships between variables and tendencies of group formation (Fig. 2), whereas LDA was used for evaluation of variables necessary to group different individuals (Thórsson et al. 2007).

The separation of species was achieved by interpreting the $L^{*}, a^{*}, b^{*}$-PCA scores (Fig. 2A) and supported by the LDA results (Table 1 ). This result is justified by the high percentage of correct classification (96.3\%) and prediction accuracy $(93.2 \%)$ of the LDA models (Table 1). Salces et al. (2005) used the CIELab parameters for cider authentication and reported that preliminary studies using PCA are needed prior to the construction of classification models. In addition, the authors reported LDA results ranging from 91 to 99\% accuracy.

The $L^{\star}, a^{\star}, b^{\star}$ and $C^{\star}$ as well as $L^{\star}, a^{\star}, b^{\star}$ and ${ }^{\circ} h$ combinations resulted in similar values for correct classification and prediction of fruit relative to the chosen combination $\left(L^{\star}, a^{\star}, b^{\star}\right)$. However, because the $L^{\star}, a^{\star}, b^{\star}$ combination used fewer variables, it simplifies the model and reduces the chances of experimental errors.

MSC was the best method for matrix correction among the methods for pre-processing of NIR spectra, with higher accuracy than the color technique in the separation of açaí and juçara fruit (Fig. 2B). NIR spectra exhibited light scat- tering as the main source of error in the raw data, and according to Mello (1998), this phenomenon is one of the main sources of error in quantitative and qualitative determinations using NIR spectroscopy and is caused by granulation and geometry of the particles in the sample. Thus, MSC and SNV techniques are indicated for correcting this anomaly (Naes et al. 2002).

In this study, MSC was the most effective pretreatment of the NIR spectra (Table 2), with fruit classification and prediction values of 98 and $97.3 \%$, respectively, results similar to those reported by Mello (1998) in a study that attempted to evaluate the performance of data pre-processing techniques to estimate nitrogen content in wheat leaves using NIR spectroscopy. Similarly, Liu et al. (2012) showed that the LS-MSV pre-processing of spectral combination was indicated to evaluate parameters such as soluble solids (SS) content ( ${ }^{\circ}$ Brix) and $\mathrm{pH}$ in fruit vinegars.

\section{CONCLUSIONS}

NIR spectroscopy associated with LDA is an accurate technique for the discrimination of plant species using fruit rather than flowers and leaves, even when the external morphological differences are minimal. The NIR spectroscopy and chemometrics provide a useful approach for authenticating fruit from Euterpe genus and can be used by the food industry to identify adulteration.

\section{ACKNOWLEDGMENTS}

The authors would like to thank the Fundação de Amparo à Pesquisa do Estado de São Paulo (FAPESP) for funding this research: process numbers 2011/22840-5, 2010/12529-8, 2008/51408-1 and 2011/19669-2.

\section{REFERENCES}

ANDRE, M. 2003. Multivariate analysis and classification of the chemical quality of 7-aminocephalosporanic acid using near-infrared reflectance spectroscopy. Anal. Chem. 75, 3460-3467.

BARNES, R.J., DHANOA, M.S. and LISTER, S.J. 1993. Correction to the description of standard normal variate (SNV) and De-Trend (DT) transformation in practical spectroscopy with applications in food and beverage analysis. J. Near Infrared Spectrosc. 1, 185-186.

CHEN, Y., XIE, M.Y., YAN, Y., ZHU, S.B., NIE, S.P., LI, C., WANG, Y.X. and GONG, X.F. 2008. Discrimination of Gonoderma lucidum according to geographical origin with near infrared diffuse reflectance spectroscopy and pattern recognition techniques. Anal. Chim. Acta 618, 121-130. COHEN, K.O., OLIVEIRA, M.S.P., CHISTE, R.C., PALLET, J.P.D. and MONTE, D.C. 2006. Quantificação do teor de 
antocianinas totais da polpa de açaí de diferentes populações de açaizeiro, p. 114, Embrapa Amazônia Oriental, Boletim de Pesquisa e Desenvolvimento, Belém.

CONFORTO, E.C. and CONTIN, D.R. 2009. Desenvolvimento do açaizeiro de terra firme, cultivar pará, sob atenuação da radiação solar em fase de viveiro. Bragantia 68, 979-983.

CORREIA, P.R.M. and FERREIRA, M.M.C. 2007.

Reconhecimento de Padrões por métodos não supervisionados: explorando procedimentos quimiométricos para tratamento dos dados analíticos. Quim. Nova 30, 481-487.

COZZOLINO, D. 2012. Recent trends on the use of infrared spectroscopy to trace and authenticate natural and agricultural food products. Appl. Spectrosc. Rev. 47, 518-530.

FARIA, M., OLIVEIRA, L.B.D. and COSTA, F.E.C. 2012.

Determinação da qualidade microbiológica de polpas de açaí congeladas comercializadas na cidade de Pouso Alegre - MG. Alim. Nutr. 23, 243-249.

FERRER, R., HERNÁNDEZ, J.M., RIVAS, J.C. and ESCRIBANO, M.T. 2011. Determination of phenolic compounds of grape skins during ripening by NIR spectroscopy. Food Sci. Technol. 44, 847-853.

FISHER, R.A. 1936. The use of multiple measures in taxonomic problems. Ann. Eugen. 7, 179-188.

HE, Y., LI, X. and DENG, X. 2006. Discrimination of varieties of tea using near infrared spectroscopy by principal component analysis and BP model. J. Food Eng. 79, 1238-1242.

HENDERSON, A., GALEANO, G. and BERNAE, R. 1995. Field Guide to the Palms of the Americas, Princeton University Press, Princeton, NJ.

IADEROZA, M., BALDINI, V.L.S., DRAETA, I.S. and BOVI, M.L.A. 1992. Anthocyaninis from fruits of açaí (Euterpe oleracea Mart.) and juçara (Euterpe edulis Mart.). Trop. Sci. 32, 41-46.

INÁCIO, M.R.C., LIMA, K.M.G., LOPES, V.G., PESSOA, J.D.C. and TEIXEIRA, G.H.A. 2013. Total anthocyanin content determination in intact açaí (Euterpe oleracea Mart.) and palmiteiro-jussara (Euterpe edulis Mart.) fruit using near infrared spectroscopy (NIR) and multivariate calibration. Food Chem. 136, 1160-1164.

JOHNSON, A.R. and WICHEM, W.D. 1998. Applied Multivariate Statistical Analysis, 4th Ed., Prentice Hall, Upper Saddle River, NJ.

KEMSLEY, E.K., RUAULT, S. and WILSON, H. 1995. Discrimination between Coffea arabica and Coffea canephora variant robusta beans using infrared spectroscopy. Food Chem. 54, 321-326.

LIU, F., KONG, W. and HE, Y. 2012. Quality determination of fruit vinegars using visible/near infrared spectroscopy and least squares-support vector machine. Afr. J. Agric. Res. 7, 2395-2404.

LOPES, T.J., XAVIER, M.F., QUADRI, M.G.N. and QUADRI, M.G.B. 2007. Antocianinas: uma breve revisão das características estruturais e de estabilidade. Rev. Bras. Agr. 13, 291-297.
LORENZI, H. 1992. Árvores Brasileiras: Manual de Identificação e Cultivo de Plantas Arbóreas Nativas do Brasil, p. 357, Plantarum, Nova Odessa.

MARCOS, C.S. and MATOS, D.M. 2003. Estrutura de Populações de Palmiteiro (Euterpe edulis Mart.) em áreas com diferentes graus de impactação na Floresta Tijuca. Florest. Ambient. 10, 27-37.

MARTO, B.T. 2007. Euterpe edulis (Palmito-Juçara). http://www.ipef.br/identificacao/euterpe.edulis.asp (accessed May 22, 2013).

MCGUIRE, R.G. 1992. Reporting of objective color measurements. HortScience 27, 254-255.

MELLO, C.A. 1998. Redes neurais e técnicas de pré-processamento de sinais em espectroscopia de reflectância do infravermelho próximo. PhD Thesis, p. 147, Instituto de Química, Universidade Estadual de Campinas.

MIRALBÉS, C. 2008. Discrimination of European wheat varieties using near infrared reflectance spectroscopy. Food Chem. 106, 386-389.

NAES, T., ISAKSSON, T., FEARN, T. and DAVIES, T. 2002. A User-Friendly Guide to Multivariate Calibration and Classification, p. 344, NIR Publication, Chichester.

NASCIMENTO, W.M.O. 2008. Açaí Euterpe oleracea Mart. Inf. Téc. Rede Sementes Amazônia 18, 1-2.

NETO, J.T.F. and OLIVEIRA, M.S.P. 2005. Variabilidade genética em progênies jovens de açaizeiro. Cerne 11, 336-341.

NETO, J.T.F.N., MULLER, A.G., OLIVEIRA, M.S.P., SANTO, D.E.S.E. and SILVA, M.R.A. 2003. Variabilidade genética entre duas procedências de açaizeiro (Euterpe oleracea Martus). Bol. Pesqui. Florest. 46, 97-104.

NICOLAÏ, B.M., BEULLENS, K., BOBLYN, E., PEIRS, A., SAEYS, W., THERON, K.I. and LAMMERTYN, J. 2007. Nondestructive measurements of fruit and vegetable quality by means of NIR spectroscopy: A review. Postharvest Biol. Technol. 46, 99-118.

OLIVEIRA, M.S.P. and NETO, J.T.F. 2005. Açaizeiro para produção de frutos em terra firme, p. 114, Embrapa Amazônia Oriental. Boletim de Pesquisa e Desenvolvimento, Brasília.

OLIVEIRA, M.S.P., CARVALHO, J.E.U. and NASCIMENTO, W.M.O. 2000. Açaí (Euterpe oleracea Mart.), p. 52, FUNEP, Jaboticabal.

PASQUINI, C. 2003. Near infrared spectroscopy: fundamentals, practical aspects and analytical applications. J. Braz. Chem. Soc. 14, 198-219.

QUEIROZ, M.H. 2000. Biologia do fruto da semente e da germinação do palmiteiro (Euterpe edulis Martius.) Arecaceae. Sellowia 49/52, 39-59.

RIBEIRO, L.O., MENDES, M.F. and PEREIRA, C.S.S. 2011. Avaliação da composição centesimal, mineral e teor de antocianinas da polpa de juçaí (Euterpe edulis Martius). Rev. Eletrônic. Teccen 4, 5-16.

RUOFF, K., LUGINBUHL, W., BOGDANOV, S., BOSSET, J.O., ESTERMANN, B., ZIOLKO, T. and AMADO, R. 2006. Authentication of the botanical origin of honey by near-infrared spectroscopy. Agric. Food Chem. 54, 6867-6872. 
SABIN, J.G., FERRÃO, M.F. and FURTADO, J.C. 2004. Análise multivariada aplicada na identificação de fármacos antidepressivos. Parte II: Análise por componentes principais (PCA) e o método de classificação SIMCA. Rev. Bras. Ciênc. Farm. 40, 387-396.

SALCES, R.M.A., GUYOT, S., HERRERO, C., BERRUETA, L.A., DRILLEAU, J.F., GALLO, B. and VICENTE, F. 2005.

Chemometric classification of Basque and French ciders based on their total polyphenol contents and CIELab parameters. Food Chem. 91, 91-98.

SAVITSKY, A. and GOLAY, M.J.E. 1964. Smoothing and differentiation by simplified least squares procedures. Anal. Chem. 36, 1627-1632.

SILVA, M.G.C.P.C., BARRETTO, W.S. and SERODIO, M.H.

2004. Caracterização química da polpa dos frutos de jussara e de açaí. In XVIII Congresso Brasileiro de Fruticultura. Florianópolis, Santa Catarina.

SILVA, O.F. and LOPES, D. 2006. Polifenóis da polpa do açaí (Euterpe oleracea). Sociedade Brasileira de Química.

SOUZA, A.M. and POPPI, R.J. 2012. Experimento didático de quimiometria para análise exploratória de óleos vegetais comestíveis por espectroscopia no infravermelho médio e análise de componentes principais: um tutorial, parte I. Quim. Nova 35, 223-229.

THÓRSSON, E.T.H., PÁLSSON, S., SIGURGEIRSSON, A. and JÓNSSON, K.A. 2007. Morphological variation among Betula nana (diploid), B. pubescens (tetraploid) and their triploid hybrids in Iceland. Ann. Bot. (Lond) 99, 1183-1193. 